DOI: $10.29303 /$ jrpb.v9i1.205

ISSN 2301-8119, e-ISSN 2443-1354

Tersedia online di http://jrpb.unram.ac.id/

\title{
PENGUKURAN EROSI PADA LAHAN RUMPUT KOLONJONO (Brachiaria mutica) DENGAN METODE PLOT KECIL DI HUTAN WANAGAMA I
}

\author{
Erosion Measurement on Grass (Brachiaria mutica) Land Using Small Plot Method \\ at Wanagama I Forest
}

\section{Irfansyah Diangga Yusuf Nugraha, Ambar Kusumandari*)}

\author{
Departemen Konservasi Sumberdaya Hutan, Fakultas Kehutanan, \\ Universitas Gadjah Mada \\ Jl. Agro, Bulaksumur No.1, Kabupaten Sleman, Yogyakarta 55281, Indonesia \\ Email $\left.{ }^{*}\right)$ ambar_kusumandari@ugm.ac.id \\ Diterima: Desember 2020 \\ Disetujui: Maret 2021
}

\begin{abstract}
Wanagama I Forest Gunungkidul has a hilly and sloping topography, so that it has a high sensitivity for erosion process. The combination of high rainfall and topographical conditions with steep slopes has the potential to produce runoff that leads to erosion. Wanagama I forest has a lot of para grass (Brachiaria mutica) planted by the surrounding community. It is very urgent to study the erosion rates of the grassland to combat land egradation. This study's objective was to measure the grassland's erosion rates and analyze the relationship between rainfall depth with runoff, runoff with erosion, and rainfall depth with erosion by using simple linear regression analysis. This study was conducted using the small plot method to determine the erosion and runoff rates. There were three small measuring plots of $22 \mathrm{~m} \times 4 \mathrm{~m}$, which are installed separately, located along the direction of the slope of the land, each representing the top, middle and bottom of the slope. The results showed that erosion rates were very low, on the upper plot was $52.52 \mathrm{~kg} / \mathrm{ha}$, the middle plot was $48.44 \mathrm{~kg} / \mathrm{ha}$, and the lower plot was $57.90 \mathrm{~kg} / \mathrm{ha}$. Rainfall greatly affected the runoff and runoff greatly affected erosion. The results also showed that the runoff on the upper plot was $18.26 \mathrm{~mm}$ with a runoff coefficient of 0.0482, the middle plot was $16.92 \mathrm{~mm}$ with a runoff coefficient of 0.0447 , and the lower plot was $20.03 \mathrm{~mm}$ with a runoff coefficient of 0.0529 and all runoff coefficient were classified as good.
\end{abstract}

Keywords: runoff; erosion; rainfall; small plot; Wanagama

\begin{abstract}
ABSTRAK
Hutan Wanagama I Gunungkidul memiliki topografi yang berbukit-bukit dan berlereng sehingga berpotensi tinggi menimbulkan erosi. Kombinasi tebal hujan yang relatif tinggi dan keadaan topografi dengan kemiringan curam berperan penting untuk menghasilkan aliran permukaan yang dapat menimbulkan erosi. Tujuan penelitian ini adalah untuk menganalisis hubungan antara tebal hujan terhadap aliran permukaan, aliran permukaan terhadap erosi, dan tebal hujan terhadap erosi dengan menggunakan analisis regresi linear
\end{abstract}


sederhana. Di Hutan Wanagama I banyak terdapat lahan rumput Kolonjono (Brachiaria mutica) yang ditanam oleh masyarakat sekitar. Oleh karena itu, sangat mendesak untuk dilakukan penelitian erosi pada lahan rumput Kolonjono tersebut untuk menghindari terjadinya degradasi lahan. Penelitian ini dilakukan dengan menggunakan metode plot kecil untuk menganalisis tingkat erosi dan aliran permukaan. Pada penggunaan lahan rumput dibuat 3 plot kecil berukuran $22 \mathrm{~m} \mathrm{x} 4 \mathrm{~m}$, yang dipasang terpisah searah lereng, masingmasing mewakili bagian atas, tengah, dan bawah lereng. Hasil penelitian menunjukkan bahwa erosi selama penelitian tergolong sangat rendah, pada plot atas sebesar $52,52 \mathrm{~kg} / \mathrm{ha}$, pada plot tengah sebesar 48,44 kg/ha, dan pada plot bawah sebesar 57,90 kg/ha. Tebal hujan sangat memengaruhi aliran permukaan dan aliran permukaan sangat memengaruhi erosi. Hasil penelitian juga menunjukkan bahwa aliran permukaan selama penelitian pada plot atas sebesar 18,26 mm dengan koefisien aliran permukaan sebesar 0,0482, pada plot tengah sebesar 16,92 mm dengan koefisien aliran permukaan sebesar 0,0447, dan pada plot bawah sebesar 20,03 mm dengan koefisien aliran permukaan sebesar 0,0529 yang kesemuanya tergolong baik.

Kata kunci: aliran permukaan; erosi; hujan; plot kecil; Wanagama

\section{PENDAHULUAN}

\section{Latar Belakang}

Sumber daya alam utama, yaitu tanah dan air, mudah mengalami kerusakan atau degradasi. Degradasi lahan dipicu oleh pemanfaatan lahan yang kurang memperhatikan keseimbangan dan kelestarian alam (Doke, et al., 2018). Kerusakan tanah dapat terjadi salah satunya disebabkan oleh erosi. Erosi merupakan bentuk degradasi lahan yang paling berbahaya yang dapat menyebabkan tanah menjadi rusak dan kehilangan kesuburan (Yuferev, et al., 2019). Besarnya erosi sangat tergantung pada faktor-faktor alam di tempat terjadinya erosi, tetapi ada yang perlu lebih diwaspadai, yaitu aktivitas penduduk maupun pengembangan infrastruktur yang ada (Subagiya, et al., 2016).

Wischmeier \& Smith (1978)
mengemukakan persamaan USLE
(universal soil loss equation) untuk
memperkirakan besarnya erosi. Persamaan
ini terdiri dari faktor-faktor yang dianggap
berperan penting terhadap erosi, antara lain
yang berkaitan dengan tebal hujan, jenis
tanah, panjang dan kemiringan lereng,
sistem tanam, dan tindakan konservasi tanah
dan air yang diterapkan. Sementara menurut
Hardjowigeno (2011), faktor yang

memengaruhi besarnya erosi adalah iklim, topografi, tanah, vegetasi, dan manusia.

Hutan Wanagama I yang termasuk ke dalam wilayah Playen, Kabupaten Gunung Kidul, Yogyakarta, memiliki iklim kering dengan rerata tebal hujan antara $1.500-$ $2.000 \mathrm{~mm} /$ tahun dan jumlah bulan kering (bulan dengan tebal hujan lebih kecil dari 60 $\mathrm{mm} /$ bulan) lebih dari 6 bulan (Suseno, 2004). Hal ini memiliki konsekuensi bahwa pada musim hujan, tebal hujan akan sangat tinggi, sehingga berpotensi besar menyebabkan erosi tinggi. Sementara pada musim kemarau akan terjadi kekeringan karena permukaan tanah yang tipis, yaitu kurang dari 10-20 cm, terutama pada lahan yang sangat miring, sehingga tidak dapat menyimpan air di dalam tanah. Selain itu, pada tempat tujuan akhir erosi, dapat ditemukan endapan sedimen yang menyebabkan ketebalan tanah hingga beberapa meter (Ernawati, 2016).

Tanah-tanah di Wanagama I memiliki kedalaman tanah yang sangat dangkal $(<10$ - $20 \mathrm{~cm}$ ) dan berbatu. Berdasarkan teksturnya, tanah di daerah ini didominasi oleh fraksi lempung dengan jenis latosol (Ratnaningrum \& Indrioko, 2014), sehingga termasuk kelas tekstur lempung, sedangkan dari segi strukturnya memiliki struktur gumpal dengan ketahanan agregat sedang sampai kuat (Supriyo, et al., 2009). Batuan 
sedimen karbonat didominasi oleh batu kapur dan napal (Ratnaningrum \& Indrioko, 2014). Hutan Wanagama I memiliki topografi yang berbukit-bukit dan berlereng, dengan ketinggian sekitar 115-205 m dpl (Nurjanto, et al., 2016). Secara umum, lapisan batuan penyusun lahan wanagama miring ke arah selatan dengan kemiringan rata-rata mencapai $15^{\circ}-30^{\circ}$ (Ernawati, 2016), yang akan memperbesar potensi erosi yang tinggi. Formasi batuan tersebut membentuk perbukitan kapur dan sering diidentikkan dengan kekurangan air. Air hujan yang turun pada lapisan batuan yang tidak dapat dilalui air akan langsung mengalir di permukaan tanah, sementara pada lapisan batuan yang dapat dilalui air, air hujan akan langsung mengalir dalam jumlah besar melalui rongga-rongga yang terbentuk dari batuan kapur yang larut. Lahan di hutan Wanagama I dapat dikategorikan sebagai berbatu, bahkan sebagian besar berupa singkapan batu (Ernawati, 2016).

Hutan Wanagama I sebagai hutan pendidikan sering dijadikan sebagai tempat penelitian, sehingga memiliki jenis-jenis pohon penelitian yang bervariasi beserta perbedaan pengelolaan dan perlakuan di dalamnya. Hutan Wanagama I yang dalam sejarahnya dibangun bersama masyarakat sekitar juga memperbolehkan masyarakat sekitar untuk menanam dan mengambil pakan ternak dan tanaman pangan dari dalam wilayah hutan Wanagama I (Ernawati, 2016). Selain itu juga banyak pengunjung ke hutan Wanagama I yang bermaksud untuk berwisata alam ataupun berkemah. Hal ini menyebabkan banyaknya variasi sistem tanam, tataguna lahan, dan aktivitas manusia di dalamnya.

Lahan rumput kolonjono (Brachiaria mutica) di petak 13 hutan Wanagama I memiliki lahan yang berbatu, dengan kondisi batu-batu besar yang tersingkap di lereng bagian atas, tetapi pada lereng bagian bawah, tanah cukup tebal, sehingga terindikasi telah terjadinya erosi yang tinggi dalam waktu yang lama. Dengan adanya penanaman rumput yang semakin meluas, penting untuk diketahui berapa besar erosi pada hutan Wanagama I, terutama pada lahan rumput kolonjono (Brachiaria mutica), untuk menghindari terjadinya degradasi lahan, sementara kerjasama dengan masyarakat sekitar perlu dipertahankan, yang belakangan telah menjadi tren pengelolaan hutan pada umumnya untuk menjaga keharmonisan pengelolaan hutan yang lestari dan berkesinambungan. Rumput merupakan tanaman yang berperan penting dalam melindungi lingkungan, termasuk menahan erosi dan stabilitas tanah (Blandon, 1985 dan Stewart \& Simons, 1994). Erosi dapat terjadi pada lahan tanaman semusim karena adanya pengolahan tanah. Hal ini akan memicu pergerakan tanah ke wilayah yang lebih rendah dalam proses erosi (McConkey, et al., 2010). Lahan pertanian sangat mudah untuk tererosi karena adanya pembersihan tumbuhan bawah (Kertis \& Livari, 2006).

\section{Tujuan}

Tujuan penelitian ini adalah untuk mengkaji tingkat erosi pada lahan rumput dan menganalisis hubungan antara tebal hujan terhadap aliran permukaan, aliran permukaan terhadap erosi, dan tebal hujan terhadap erosi dengan menggunakan analisis regresi linear sederhana.

\section{METODE PENELITIAN}

\begin{abstract}
Alat dan Bahan
Alat yang digunakan dalam penelitian ini adalah plot kecil untuk mengukur aliran permukaan dan erosi, dibuat dari seng, bambu, kawat, pipa paralon, drum, dan plastik (Gambar 1, 2, dan 3). Klinometer digunakan untuk mengukur kemiringan lahan. Ombrometer manual digunakan untuk mengukur tebal hujan. Gelas ukur digunakan untuk mengambil sampel sedimen dari dalam drum. Kertas saring digunakan untuk menyaring dan menyimpan sampel sedimen. Timbangan digunakan untuk mengukur berat kertas saring sebelum dan sesudah terisi oleh
\end{abstract}


sampel sedimen. Oven digunakan untuk mengeringkan sampel, sedangkan eksikator digunakan untuk mempertahankan kelembaban sampel. Software yang digunakan adalah Microsoft Excel 2010 dan SPSS 22. Bahan yang digunakan adalah data volume air dan berat sedimen yang diambil dari dalam drum di plot kecil, data tebal hujan dari ombrometer, dan peta Hutan Wanagama I.

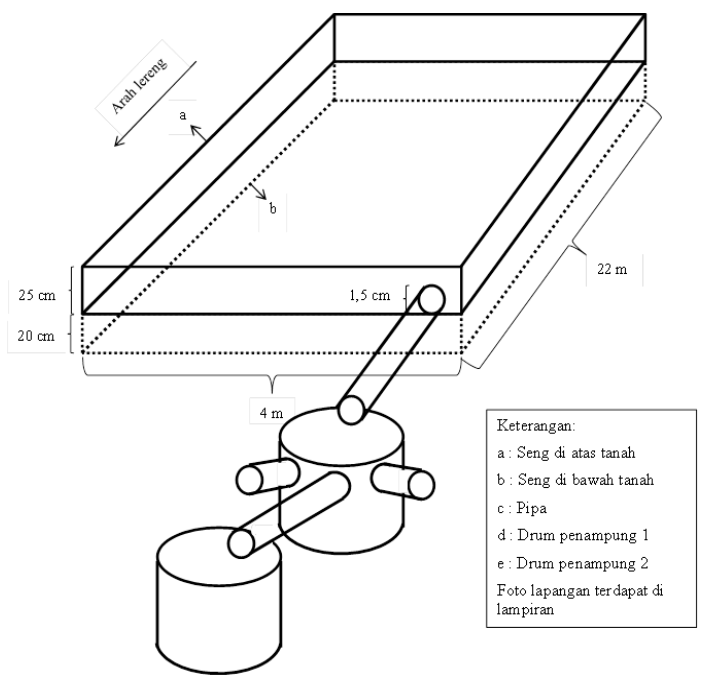

Gambar 1. Sketsa plot kecil

Plot kecil yang dibuat berukuran $22 \mathrm{~m}$ x $4 \mathrm{~m}$ (Gambar 1). Untuk membuat plot kecil, digunakan seng selebar $45 \mathrm{~cm}$, dalam hal ini $20 \mathrm{~cm}$ tertanam di tanah dan $25 \mathrm{~cm}$ berdiri tegak di atas permukaan tanah. Seng berfungsi sebagai pembatas sehingga air mengalir menuju drum penampung dan plot kecil terbebas dari pengaruh dari luar plot. Pemasangan plot kecil dilakukan memanjang searah lereng agar air mengalir menuju drum penampung. Plot kecil dan drum penampung aliran permukaan dihubungkan menggunakan pipa $P V C$ berdiameter $1,5 \mathrm{~cm}$. Drum penampung (Gambar 3) ditutup menggunakan plastik agar volume air pada drum hanya berasal dari aliran permukaan yang terjadi di dalam plot kecil. Plot dipasang di lapangan pada 3 lokasi, yaitu pada lereng atas, tengah dan bawah. Plot atas memiliki kelerengan 9\%, plot tengah $7 \%$, dan plot bawah $12 \%$.

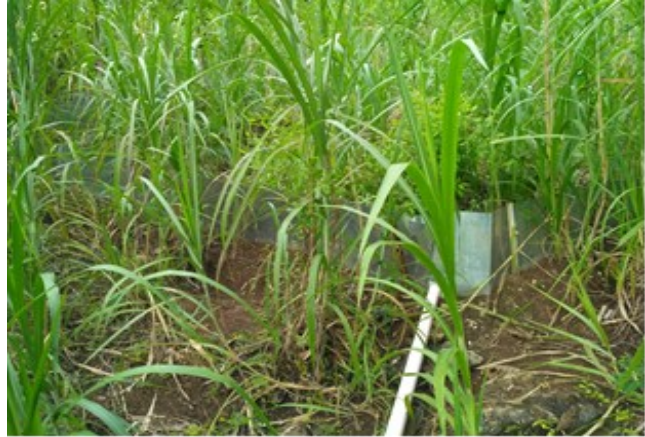

Gambar 2. Plot kecil dan pipa penghubung drum

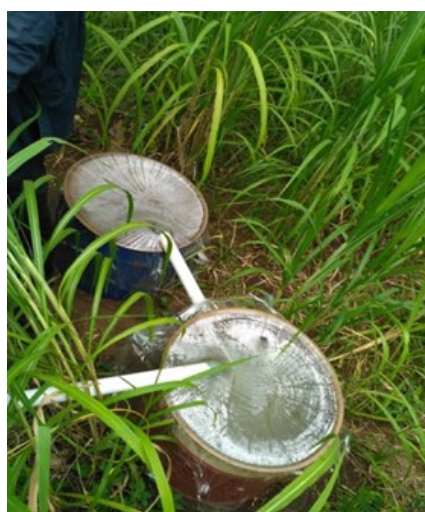

Gambar 3. Drum penampung air

\section{Metode}

Pengambilan Data

Pengambilan data tebal hujan dilakukan dengan dua ombrometer manual yang dipasang di sekitar lokasi penelitian. Langkah pengambilan data tebal hujan antara lain mengukur volume tebal air hujan yang tertampung di ombrometer manual dan membagi volume tersebut dengan luas penampung ombrometer $\left(\mathrm{mm}^{2}\right)$ sehingga didapatkan tebal hujan (mm). Bila ombrometer dipasang lebih dari satu, tebal hujan per kejadian hujan diperoleh dari ratarata aritmatik semua ombrometer yang terpasang.

Pengambilan data erosi dilakukan dengan metode plot kecil, sehingga didapatkan data erosi pada tiap kejadian hujan. Terdapat 3 plot kecil berukuran $22 \mathrm{~m}$ x $4 \mathrm{~m}$, yang dipasang terpisah, dibuat searah lereng dan kontur tanah, masing-masing mewakili bagian atas, tengah, dan bawah lereng. Adapun langkah pengambilan data berdasarkan Kusumandari (2013) adalah mengukur tinggi muka air (TMA) pada kedua drum penampung, kemudian air 
dalam drum diaduk agar diperoleh suspensi yang merata. Sampel diambil sebanyak 500 $\mathrm{ml}$ menggunakan gelas ukur, untuk kemudian disaring menggunakan kertas saring yang telah dioven dan telah diketahui beratnya (a gram). Drum penampung dibersihkan dan dikembalikan ke tempatnya semula. Sementara kertas saring berisi sampel dioven selama 48 jam pada suhu $70^{\circ} \mathrm{C}$, lalu dimasukkan ke dalam eksikator selama 24 jam dan kemudian ditimbang (b gram) sehingga diperoleh berat sampel erosi (b-a gram). Data yang diperoleh kemudian diolah lebih lanjut menggunakan software Microsoft Excel 2010 dan SPSS 22.

\section{Analisis Data}

Langkah pertama perhitungan erosi dengan metode plot kecil dilakukan berdasarkan Kusumandari (2013) dengan menghitung volume drum (ml) menggunakan Persamaan 1.

$\mathrm{VD}=\frac{1}{4} x(\pi) x\left(d^{2}\right) x T M A$

Keterangan:

$\mathrm{VD}=$ volume air yang tertampung di drum saat sampel diambil (ml)

$\mathrm{D}=$ diameter drum penampung (cm)

$\mathrm{TMA}=$ tinggi muka air yang terdapat dalam drum penampung saat sampel diambil $(\mathrm{cm})$

Selanjutnya dihitung tebal aliran permukaan menggunakan Persamaan 2.

$\mathrm{RO}=\frac{\text { Volume drum }}{\text { Luas plot }\left(\mathrm{cm}^{2}\right)} \times 10 \mathrm{~mm}$

Kemudian dihitung besar erosi per drum $(\mathrm{g})$ menggunakan Persamaan 3.

$\mathrm{W}_{\mathrm{D}}=\frac{W s}{V s} \times V d$

Keterangan:

$\mathrm{WD}=$ berat erosi yang tertampung $\mathrm{di}$ drum $(\mathrm{g})$

$\mathrm{Ws}=$ berat suspense $(\mathrm{g})$

$\mathrm{Vs}=$ volume sampel $(\mathrm{ml})$
$\mathrm{Vd}=$ volume drum $(\mathrm{ml})$

Selanjutnya dihitung besar erosi dalam satuan $\mathrm{kg} / \mathrm{ha}$ menggunakan Persamaan 4.

$\mathrm{WT}=\frac{W_{D 1}+\left(3 \times W_{D 2}\right)}{L P\left(\mathrm{~m}^{2}\right)} \times 10 \frac{\mathrm{kg}}{\mathrm{ha}}$

Keterangan:

$\mathrm{WT}=\operatorname{erosi}(\mathrm{kg} / \mathrm{ha})$

$\mathrm{W}_{\mathrm{D} 1}=$ erosi pada drum penampung

ke-1 (g)

$\mathrm{W}_{\mathrm{D} 2}=$ erosi pada drum penampung

ke-2 (g)

$3=$ jumlah lubang yang digunakan

$\mathrm{LP}=$ luas plot kecil yang digunakan $\left(\mathrm{m}^{2}\right)$

Nilai aliran permukaan akan digunakan untuk mengetahui koefisien aliran permukaan. Koefisien aliran permukaan diklasifikasikan menurut Peraturan Direktur Jenderal Rehabilitasi Lahan dan Perhutanan Sosial tentang Pedoman Monitoring dan Evaluasi Alirani Sungai (P.04/V-SET/2009) seperti disajikan pada Tabel 1.

Tabel 1. Klasifikasi koefisien aliran permukaan (C) tahunan

\begin{tabular}{cc}
\hline Kelas & Nilai C \\
\hline Baik & $<0,25$ \\
Sedang & $0,25-0,50$ \\
Jelek & $>0,50$ \\
\hline
\end{tabular}

Nilai kemiringan lereng diklasifikasikan berdasarkan Peraturan Direktur Jenderal Bina Pengelolaan Daerah Aliran Sungai dan Perhutanan Sosial Nomor: P. 4/V-SET/2013 tentang Petunjuk Teknis Penyusunan Data Spasial Lahan Kritis ditunjukkan pada Tabel 2.

Tabel 2. Klasifikasi kemiringan lereng

\begin{tabular}{ll}
\hline Kelas & Kemiringan lereng (\%) \\
\hline Datar & $<8$ \\
Landai & $8-15$ \\
Agak curam & $16-25$ \\
Curam & $26-40$ \\
Sangat curam & $>40$ \\
\hline
\end{tabular}


Besar erosi dapat diklasifikan berdasarkan tingkat bahaya erosi (TBE) yang dikeluarkan oleh kementrian kehutanan. Klasifikasi ini penting diketahui sebagai alat bantu penentuan usulan teknik konservasi dan air yang dapat diterapkan pada lokasi tersebut. Klasifikasi tingkat bahaya erosi yang dikeluarkan oleh kementrian kehutanan tahun 2009 (P.32/MENHUT-II/ 2009) dapat dilihat pada Tabel 3.

Tabel 3. Klasifikasi tingkat bahaya erosi (TBE) pada berbagai macam solum tanah

\begin{tabular}{lcccccc}
\hline \multirow{2}{*}{ Solum tanah $(\mathbf{c m})$} & \multicolumn{5}{c}{ Kelas erosi } \\
\cline { 2 - 7 } & I & II & III & IV & V \\
\cline { 2 - 7 } & \multicolumn{5}{c}{ Erosi (ton/ha/tahun) } & \\
\cline { 2 - 7 } & $<\mathbf{1 5}$ & $\mathbf{1 6 - 6 0}$ & $\mathbf{6 0 - 1 8 0}$ & $\mathbf{1 8 0 - 4 8 0}$ & $>\mathbf{4 8 0}$ \\
\hline Dalam & SR & R & S & B & SB \\
$>90$ & 0 & 1 & II & III & IV \\
\hline Sedang & R & S & B & SB & SB \\
$60-90$ & I & II & III & IV & IV \\
\hline Dangkal & S & B & SB & SB & SB \\
$30-60$ & II & III & IV & IV & IV \\
\hline Sangat dangkal & B & SB & SB & SB & SB \\
$<30$ & III & IV & IV & IV & IV \\
\hline Kan
\end{tabular}

Keterangan: 0 - SR = Sangat Ringan, I - R = Ringan, II $-\mathrm{S}=$ Sedang, III $-\mathrm{B}=$ Berat, IV $-\mathrm{SB}=$ Sangat Berat

Pengaruh antara tebal hujan terhadap aliran permukaan dan pengaruh antara aliran permukaan terhadap erosi dianalisis menggunakan analisis regresi linear sederhana. Dalam analisis pengaruh tebal hujan terhadap aliran permukaan maka aliran permukaan merupakan variabel bergantung. Adapun untuk menganalisis hubungan aliran permukaan dengan erosi, maka erosi merupakan variabel bergantung.

\section{HASIL DAN PEMBAHASAN}

Selama pengamatan dilakukan, yaitu dari bulan Maret sampai dengan Mei tahun 2018, terdapat 22 kejadian hujan. Tebal hujan terrendah yang terjadi sebesar 7,42 $\mathrm{mm}$ dan tebal hujan terbesar yang terjadi sebesar 40,06 $\mathrm{mm}$, dengan rerata sebesar 17,21 mm per kejadian hujan. Aliran permukaan terrendah yang terjadi sebesar 0,00 mm pada ketiga plot dan aliran permukaan terbesar yang terjadi sebesar $3,25 \mathrm{~mm}$ pada plot atas, $3,10 \mathrm{~mm}$ pada plot tengah, dan 3,62 mm pada plot bawah. Erosi terendah yang terjadi sebesar $0,00 \mathrm{~kg} / \mathrm{ha}$ pada ketiga plot dan erosi terbesar yang terjadi sebesar $9,24 \mathrm{~kg} / \mathrm{ha}$ pada plot atas, $7,90 \mathrm{~kg} / \mathrm{ha}$ pada plot tengah, dan 12,10 $\mathrm{kg} / \mathrm{ha}$ pada plot bawah. Data hasil perhitungan disajikan pada Tabel 4 dan Gambar 4.

Tabel 4. Hasil perhitungan aliran permukaan dan erosi

\begin{tabular}{cccccccccc}
\hline \multirow{2}{*}{ No } & Tebal Hujan & $\mathbf{t}$ & \multirow{2}{*}{$\mathbf{2}(\mathbf{m m} / \mathbf{j a m})$} & \multicolumn{3}{c}{ RO $(\mathbf{m m})$} & \multicolumn{3}{c}{ Erosi (Kg/Ha) } \\
\cline { 5 - 10 } & $\mathbf{j a m})$ & & PA & PT & PB & PA & PT & PB \\
\hline 1 & 7,42 & 1,27 & 5,86 & 0,00 & 0,00 & 0,00 & 0,00 & 0,00 & 0,00 \\
2 & 7,58 & 0,67 & 11,37 & 0,00 & 0,00 & 0,00 & 0,00 & 0,00 & 0,00 \\
3 & 8,00 & 0,58 & 13,72 & 0,00 & 0,00 & 0,00 & 0,00 & 0,00 & 0,00 \\
4 & 8,53 & 3,97 & 2,15 & 0,00 & 0,00 & 0,00 & 0,00 & 0,00 & 0,00 \\
5 & 9,21 & 0,75 & 12,28 & 0,00 & 0,00 & 0,00 & 0,00 & 0,00 & 0,00 \\
6 & 9,37 & 0,92 & 10,22 & 0,12 & 0,12 & 0,14 & 0,09 & 0,14 & 0,23 \\
7 & 11,95 & 1,42 & 8,43 & 0,32 & 0,39 & 0,29 & 0,57 & 0,86 & 0,52 \\
8 & 12,32 & 0,97 & 12,74 & 0,20 & 0,20 & 0,17 & 0,28 & 0,61 & 0,45 \\
9 & 12,53 & 2,47 & 5,08 & 0,12 & 0,09 & 0,17 & 0,46 & 0,19 & 0,38 \\
10 & 13,32 & 1,33 & 9,99 & 0,14 & 0,13 & 0,20 & 0,26 & 0,23 & 0,37
\end{tabular}




\begin{tabular}{cccccccccc}
\hline \hline & & & & & & & & & \\
11 & 14,37 & 0,67 & 21,56 & 0,64 & 0,64 & 0,67 & 4,21 & 1,66 & 1,73 \\
12 & 14,84 & 0,87 & 17,13 & 0,81 & 0,64 & 0,72 & 1,62 & 1,28 & 1,88 \\
13 & 18,06 & 3,50 & 5,16 & 0,81 & 0,72 & 0,85 & 1,95 & 1,88 & 1,71 \\
14 & 19,00 & 1,18 & 16,06 & 0,49 & 0,52 & 0,61 & 0,89 & 2,30 & 1,46 \\
15 & 19,21 & 2,28 & 8,41 & 0,80 & 0,72 & 0,87 & 2,07 & 1,88 & 2,43 \\
16 & 20,74 & 2,25 & 9,22 & 1,68 & 1,30 & 1,97 & 9,24 & 4,70 & 4,78 \\
17 & 23,74 & 1,10 & 21,58 & 1,33 & 1,78 & 1,17 & 3,29 & 7,90 & 2,97 \\
18 & 23,95 & 0,82 & 29,33 & 1,68 & 1,17 & 1,43 & 3,50 & 2,90 & 3,83 \\
19 & 24,69 & 1,00 & 24,69 & 1,77 & 1,43 & 1,78 & 4,06 & 3,42 & 4,98 \\
20 & 27,16 & 1,25 & 21,73 & 1,85 & 1,85 & 1,85 & 6,67 & 6,99 & 7,23 \\
21 & 32,48 & 3,50 & 9,28 & 2,25 & 2,12 & 3,52 & 6,11 & 5,56 & 12,10 \\
22 & 40,06 & 1,42 & 28,28 & 3,25 & 3,10 & 3,62 & 7,25 & 5,94 & 10,85 \\
\hline Jumlah & 378,53 & 34,19 & 304,27 & 18,26 & 16,92 & 20,03 & 52,52 & 48,44 & 57,90 \\
Rerata & 17,21 & 1,55 & 13,83 & 0,83 & 0,77 & 0,91 & 2,39 & 2,20 & 2,63 \\
\hline Kerancy
\end{tabular}

Keterangan: $\mathrm{t}=$ Lama waktu hujan, $\mathrm{I}=$ Intensitas hujan, $\mathrm{RO}=$ Runoff, $\mathrm{PA}=$ Plot atas, $\mathrm{PT}=$ Plot tengah, PB $=$ Plot bawah

Di daerah beriklim basah seperti Indonesia yang berada di daerah tropika, hujan berperan sangat penting pada terjadinya erosi. Tebal hujan menunjukkan jumlah volume air yang turun pada area tertentu. Semakin banyaknya air yang turun, maka semakin besar pula kekuatan air untuk menimbulkan erosi, baik dari kekuatan dispersi hujan terhadap tanah, maupun kemampuannya untuk menjadi aliran permukaan (Arsyad, 2010). Pada Tabel 4 dapat dilihat bahwa secara umum, semakin besar tebal hujan maka semakin besar pula aliran permukaan yang terjadi.

Banyaknya jumlah hujan lebat atau hujan yang memiliki intensitas hujan tinggi seharusnya menghasilkan aliran permukaan dan erosi yang semakin meningkat pula, terutama pada hujan lebat yang terjadi dalam waktu singkat. Arsyad (2010) menyatakan bahwa pada hujan lebat yang terjadi dalam waktu yang singkat, kondensasi (pengembunan), adsorpsi, perkolasi, evaporasi, dan transpirasi terjadi dalam jumlah yang kecil (hanya persepuluh $\mathrm{mm}$ per jam) sedangkan tebal hujan, aliran permukaan, dan air tersimpan dapat sampai beberapa puluh $\mathrm{mm}$ per jam. Dalam penelitian ini didapatkan hasil nilai korelasi antara intensitas hujan terhadap aliran permukaan sebesar 0,630 pada plot atas, 0,619 pada plot tengah dan 0,487 pada plot bawah. Adapun nilai korelasi antara intensitas hujan terhadap erosi diperoleh sebesar 0,472 pada plot atas, 0,554 pada plot tengah dan 0,460 pada plot bawah seperti dapat dilihat pada Tabel 5 dan Tabel 6 .

Tabel 5. Pengaruh intensitas hujan terhadap aliran permukaan

\begin{tabular}{cccccc}
\hline Plot & R & R Square & $\begin{array}{c}\text { Adjusted } \\
\text { R Square }\end{array}$ & $\begin{array}{c}\text { Std. error of the } \\
\text { estimate }\end{array}$ & Durbin-Watson \\
\hline Upper plot & 0,630 & 0,397 & 0,367 & 0,72052 & 0,948 \\
Middle plot & 0,619 & 0,383 & 0,352 & 0,68415 & 0,865 \\
Lower plot & 0,487 & 0,237 & 0,199 & 0,96068 & 0,901 \\
\hline
\end{tabular}

Tabel 6. Pengaruh intensitas hujan terhadap erosi

\begin{tabular}{cccccc}
\hline Plot & $\mathbf{R}$ & R Square & $\begin{array}{c}\text { Adjusted } \\
\text { R Square }\end{array}$ & $\begin{array}{r}\text { Std. error of the } \\
\text { estimate }\end{array}$ & Durbin-Watson \\
\hline Upper plot & 0,472 & 0,222 & 0,183 & 2,52336 & 1,370 \\
Middle plot & 0,554 & 0,307 & 0,272 & 2,13096 & 1,119 \\
Lower plot & 0,460 & 0,211 & 0,172 & 3,16145 & 0,781 \\
\hline
\end{tabular}

Hasil ini sejalan dengan penelitianpenelitian sebelumnya. Meningkatnya intensitas hujan diikuti dengan meningkatkan aliran permukaan yang 
terjadi (Liu, et al., 2019; Wang, et al., 2018), mempercepat waktu terjadinya aliran permukaan dan meningkatkan koefisien aliran permukaan (Wang, et al., 2018), dan berpengaruh signifikan terhadap proses erosi (Wu, et al., 2018). Hasil penelitian ini kemungkinan dipengaruhi oleh besarnya kapasitas infiltrasi di Hutan Wanagama I karena tanahnya yang didominasi oleh batuan kapur yang berporus. Arsyad (2010) menyatakan, pada hujan lebat yang terjadi dalam waktu singkat sehingga intensitas hujannya tinggi, aliran permukaan hanya dapat dikurangi dengan memperbesar kemampuan tanah menyimpan air melalui perbaikan kapasitas infiltrasi.

Selama hujan berlangsung, laju aliran permukaan akan meningkat dengan semakin berkurangnya kapasitas infiltrasi hingga pada akhirnya mencapai nilai maksimum yang konstan. Semakin banyak air hujan yang menjadi aliran permukaan, maka akan semakin besar pula kekuatan aliran permukaan untuk menimbulkan erosi. Banyaknya air hujan yang menjadi aliran permukaan ditunjukkan dengan nilai koefisien aliran permukaan (C). Hasil perhitungan menunjukkan bahwa 4,82\% dari tebal hujan yang turun di plot atas menjadi aliran permukaan, $4,47 \%$ dari tebal hujan yang turun di plot tengah menjadi aliran permukaan, dan 5,29\% dari tebal hujan yang turun di plot bawah menjadi aliran permukaan. Nilai koefisien aliran permukaan pada ketiga plot tersebut tergolong baik menurut Tabel 1. Ini menunjukkan baiknya infiltrasi air hujan ke dalam tanah yang terjadi di lokasi penelitian, sehingga hanya sebagian kecil dari air hujan yang turun yang menjadi aliran permukaan langsung yang kemudian menurunkan resiko terjadinya erosi dan banjir. Kemampuan menyerap air yang baik ini dapat menunjukkan kemampuan tanah yang baik untuk menyimpan air. Sebaliknya, hal ini juga dapat mengindikasikan karakteristik tanah Hutan Wanagama I yang berupa tanah batuan kapur yang porus sehingga air langsung lolos masuk ke dalam aliran sungai bawah tanah.

Ketiga plot yang dipasang pada lokasi penelitian memiliki kemiringan lereng yang berbeda. Plot atas memiliki kelerengan 9\%, plot tengah memiliki kelerengan $7 \%$, dan plot bawah memiliki kelerengan 12\%. Berdasarkan Tabel 2, maka plot atas dan plot bawah termasuk ke dalam klasifikasi landai, sementara plot tengah termasuk ke dalam klasifikasi datar. Hal ini dapat membantu menjelaskan besar aliran permukaan dan erosi yang terjadi di ketiga plot kecil yang terpasang. Data pada Tabel 4 menunjukkan bahwa semakin miring lereng maka semakin besar aliran permukaan dan erosi yang terjadi, yang terlihat dari total dan rerata aliran permukaan dan erosi yang terjadi. Hal ini juga menunjukkan bahwa semakin besar aliran permukaan maka semakin besar erosi yang terjadi dikarenakan semakin besarnya jumlah dan kekuatan aliran permukaan untuk menimbulkan erosi (Arsyad, 2010).

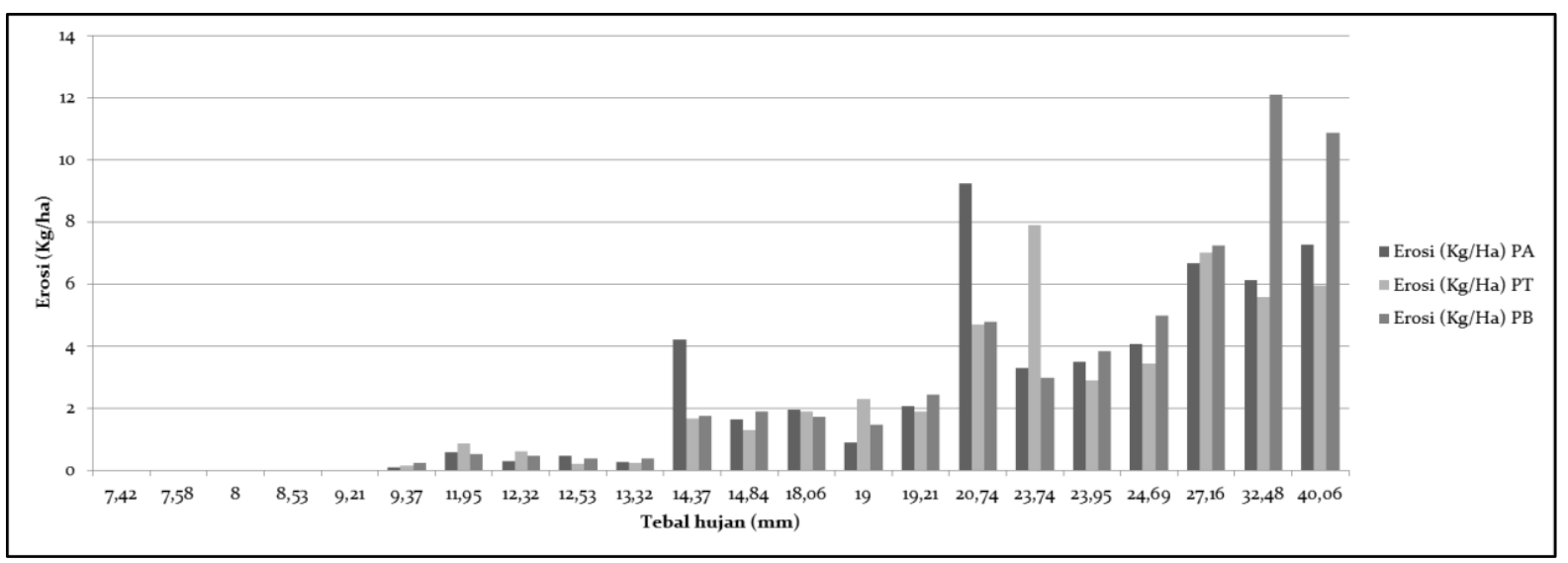

Gambar 4. Grafik erosi pada lahan rumput di ketiga plot

$(\mathrm{PA}=$ plot atas, $\mathrm{PT}=$ plot tengah, $\mathrm{PB}=$ plot bawah $)$ 
Pada Gambar 4 yang merupakan grafik dari Tabel 4, terdapat beberapa nilai ekstrim yang berbeda dengan sebagian besar nilai lain dalam kelompoknya. Nilai-nilai tersebut antara lain terdapat pada erosi plot atas pada tebal hujan $14,37 \mathrm{~mm}$, erosi plot atas pada tebal hujan $20,74 \mathrm{~mm}$, erosi plot tengah pada tebal hujan 23,74, erosi plot bawah pada tebal hujan $32,48 \mathrm{~mm}$, dan erosi plot bawah pada tebal hujan 40,06 $\mathrm{mm}$. Hal ini kemungkinan besar diakibatkan karena erosi terjadi pada kejadian hujan setelah adanya aktivitas pemanenan rumput pada lahan pengamatan yang dilakukan oleh warga. Hal ini terjadi karena memang lahan yang dijadikan sebagai plot pengamatan merupakan lahan hak warga. Pemanfaatan lahan tanpa dibarengi dengan upaya konservasi tanah dan air akan menurunkan produktivitas lahan (Ribolzil, et al., 2017). Selanjutnya tingkat erosi akan semakin meningkat (Yu, et al., 2017; Van Loo et al., 2017). Tabel 7 berisikan data pengamatan rumput pada ketiga plot yang terjadi sepanjang waktu penelitian.

Tabel 7. Data Pengamatan Pemanenan Rumput Kolonjono di Tiap Plot

\begin{tabular}{ccccc}
\hline No & Tanggal & Lokasi plot & Nama pemanen & Berat rumput (kg) \\
\hline 1 & $2 / 3 / 2018$ & Plot bawah & Pak Pardiyono & 29,5 \\
2 & $4 / 3 / 2018$ & Plot bawah & Pak Paimin & 27 \\
3 & $6 / 3 / 2018$ & Plot bawah & Pak Paimin & 25 \\
4 & $20 / 3 / 2018$ & Plot atas & Pak Sukiran & 24,5 \\
5 & $21 / 3 / 2018$ & Plot atas & Pak Sukiran & 21 \\
6 & $14 / 4 / 2018$ & Plot tengah & Pak Paimin & 32,5 \\
7 & $15 / 4 / 2018$ & Plot tengah & Pak Paimin & 28,5 \\
8 & $16 / 4 / 2018$ & Plot tengah & Pak Paimin & 25,5 \\
9 & $10 / 5 / 2018$ & Plot tengah & Pak Paimin & 25 \\
\hline
\end{tabular}

Tabel 8 menampilkan urutan kejadian yang terjadi pada ketiga plot kecil untuk memudahkan pembaca menggambarkan pengaruh kegiatan pemanenan terhadap besarnya erosi yang terjadi pada tiap plot.

Tabel 8. Jenis dan waktu kejadian

\begin{tabular}{cccccccccc}
\hline \multirow{2}{*}{ No } & \multirow{2}{*}{ Tanggal } & \multirow{2}{*}{ Kejadian } & Tebal & \multicolumn{3}{c}{ RO $(\mathbf{m m})$} & \multicolumn{3}{c}{ Erosi (Kg/Ha) } \\
\cline { 5 - 10 } & & hujan $(\mathbf{m m})$ & PA & PT & PB & PA & PT & PB \\
\hline 1 & $23 / 2 / 2018$ & Hujan & 9,37 & 0,12 & 0,12 & 0,14 & 0,09 & 0,14 & 0,23 \\
2 & $1 / 3 / 2018$ & Hujan & 12,53 & 0,12 & 0,09 & 0,17 & 0,46 & 0,19 & 0,38 \\
3 & $2 / 3 / 2018$ & Panen plot bawah & - & - & - & - & - & - & - \\
4 & $4 / 3 / 2018$ & Panen plot bawah & - & - & - & - & - & - & - \\
5 & $5 / 3 / 2018$ & Hujan & 40,06 & 3,25 & 3,10 & 3,62 & 7,25 & 5,94 & 10,85 \\
6 & $6 / 3 / 2018$ & Panen plot bawah & - & - & - & - & - & - & - \\
7 & $7 / 3 / 2018$ & Hujan & 32,48 & 2,25 & 2,12 & 3,52 & 6,11 & 5,56 & 12,10 \\
8 & $8 / 3 / 2018$ & Hujan & 20,74 & 1,68 & 1,30 & 1,97 & 9,24 & 4,70 & 4,78 \\
9 & $11 / 3 / 2018$ & Hujan & 19,21 & 0,80 & 0,72 & 0,87 & 2,07 & 1,88 & 2,43 \\
10 & $19 / 3 / 2018$ & Hujan & 7,42 & 0,00 & 0,00 & 0,00 & 0,00 & 0,00 & 0,00 \\
11 & $20 / 3 / 2018$ & Panen plot atas & - & - & - & - & - & - & - \\
12 & $21 / 3 / 2018$ & Panen plot atas & - & - & - & - & - & - & - \\
13 & $24 / 3 / 2018$ & Hujan & 13,32 & 0,14 & 0,13 & 0,20 & 0,26 & 0,23 & 0,37 \\
14 & $25 / 3 / 2018$ & Hujan & 18,06 & 0,81 & 0,72 & 0,85 & 1,95 & 1,88 & 1,71 \\
15 & $26 / 3 / 2018$ & Hujan & 14,37 & 0,64 & 0,64 & 0,67 & 4,21 & 1,66 & 1,73 \\
16 & $28 / 3 / 2018$ & Hujan & 8,53 & 0,00 & 0,00 & 0,00 & 0,00 & 0,00 & 0,00 \\
17 & $7 / 4 / 2018$ & Hujan & 24,69 & 1,77 & 1,43 & 1,78 & 4,06 & 3,42 & 4,98 \\
18 & $7 / 4 / 2018$ & Hujan & 23,95 & 1,68 & 1,17 & 1,43 & 3,50 & 2,90 & 3,83 \\
19 & $8 / 4 / 2018$ & Hujan & 14,84 & 0,81 & 0,64 & 0,72 & 1,62 & 1,28 & 1,88 \\
20 & $11 / 4 / 2018$ & Hujan & 19,00 & 0,49 & 0,52 & 0,61 & 0,89 & 2,30 & 1,46
\end{tabular}




\begin{tabular}{llcccccccc}
21 & $14 / 4 / 2018$ & Panen plot tengah & - & - & - & - & - & - & - \\
22 & $15 / 4 / 2018$ & Panen plot tengah & - & - & - & - & - & - & - \\
23 & $16 / 4 / 2018$ & Panen plot tengah & - & - & - & - & - & - & - \\
24 & $16 / 4 / 2018$ & Hujan & 23,74 & 1,33 & 1,78 & 1,17 & 3,29 & 7,90 & 2,97 \\
25 & $17 / 4 / 2018$ & Hujan & 11,95 & 0,32 & 0,39 & 0,29 & 0,57 & 0,86 & 0,52 \\
26 & $18 / 4 / 2018$ & Hujan & 12,32 & 0,20 & 0,20 & 0,17 & 0,28 & 0,61 & 0,45 \\
27 & $21 / 4 / 2018$ & Hujan & 8,00 & 0,00 & 0,00 & 0,00 & 0,00 & 0,00 & 0,00 \\
28 & $24 / 4 / 2018$ & Hujan & 27,16 & 1,85 & 1,85 & 1,85 & 6,67 & 6,99 & 7,23 \\
29 & $10 / 5 / 2018$ & Panen plot tengah & - & - & - & - & - & - & - \\
30 & $21 / 5 / 2018$ & Hujan & 7,58 & 0,00 & 0,00 & 0,00 & 0,00 & 0,00 & 0,00 \\
31 & $22 / 5 / 2018$ & Hujan & 9,21 & 0,00 & 0,00 & 0,00 & 0,00 & 0,00 & 0,00 \\
\hline
\end{tabular}

Keterangan: $\mathrm{RO}=$ Runoff, $\mathrm{PA}=$ Plot atas, $\mathrm{PT}=$ Plot tengah, $\mathrm{PB}=$ Plot bawah

Kerapatan rumput di ketiga plot tidak selalu sama sepanjang waktu penelitian. Hal ini disebabkan karena pemilik lahan tetap melakukan pemanenan sebagai usaha penyediaan pakan bagi ternak mereka. Waktu pemanenan umumnya dilakukan tiap hari atau dua hari sekali, tetapi di lokasi penelitian tidak memiliki jadwal yang pasti, karena dilakukan sesuai kebutuhan dan petani memiliki lahan rumput lain untuk dipanen. Setelah pemanenan dilakukan, tutupan rumput kolonjono pada plot kecil menjadi semakin jarang. Hal ini dapat menyebabkan meningkatnya erosi yang terjadi karena hilangnya fungsi vegetasi yang sebelumnya mempengaruhi aliran permukaan dan erosi yang telah terjadi. Hal ini diminimalisir, dengan meminta tolong kepada petani agar tidak menghabiskan seluruh rumput yang ada di dalam plot, dan dibantu pula dengan kebiasaan petani yang meninggalkan limbah bekas panen di lokasi pemanenan. Limbah-limbah ini dapat berbentuk batang, potongan tunas, maupun rumput kering. Petani juga seringkali tidak memanen rumput-rumput muda.

Tabel 9. Pengaruh tebal hujan terhadap aliran permukaan

\begin{tabular}{cccccc}
\hline Plot & R & R Square & $\begin{array}{c}\text { Adjusted R } \\
\text { Square }\end{array}$ & $\begin{array}{c}\text { Std. error of the } \\
\text { estimate }\end{array}$ & Durbin-Watson \\
\hline Upper plot & 0,971 & 0,943 & 0,940 & 0,22108 & 1,788 \\
Middle plot & 0,973 & 0,947 & 0,944 & 0,20065 & 1,548 \\
Lower plot & 0,955 & 0,912 & 0,907 & 0,32686 & 2,104 \\
\hline
\end{tabular}

Tabel 10. Pengaruh tebal hujan terhadap erosi

\begin{tabular}{cccccc}
\hline Plot & $\mathbf{R}$ & R Square & $\begin{array}{c}\text { Adjusted } \\
\text { R Square }\end{array}$ & $\begin{array}{c}\text { Std. error of } \\
\text { the estimate }\end{array}$ & Durbin-Watson \\
\hline Upper plot & 0,816 & 0,665 & 0,648 & 1,65593 & 2,264 \\
Middle plot & 0,864 & 0,747 & 0,734 & 1,28812 & 1,766 \\
Lower plot & 0,934 & 0,872 & 0,866 & 1,27283 & 1,375 \\
\hline
\end{tabular}

Tabel 11. Pengaruh aliran permukaan terhadap erosi

\begin{tabular}{cccccc}
\hline Plot & R & R Square & $\begin{array}{c}\text { Adjusted } \\
\text { R Square }\end{array}$ & $\begin{array}{c}\text { Std. error of the } \\
\text { estimate }\end{array}$ & Durbin-Watson \\
\hline Upper plot & 0,886 & 0,784 & 0,773 & 1,32944 & 2,143 \\
Middle plot & 0,913 & 0,833 & 0,825 & 1,04550 & 1,583 \\
Lower plot & 0,986 & 0,971 & 0,970 & 0,60243 & 1,312 \\
\hline
\end{tabular}

Dapat dilihat pada Tabel 8 bahwa nilai erosi yang besar pada plot tertentu muncul setelah terjadi pemanenan sebelumnya pada plot tersebut dan nilai erosi kemudian berangsur turun kembali. Hal ini terjadi selain karena hilangnya rumput yang berfungsi sebagai pengintersepsi air hujan yang turun ke tanah, penahan laju aliran 
permukaan, dan pengikat tanah dengan akarnya, juga disebabkan pada kegiatan pemanenan terjadi pemadatan dan penutupan tanah oleh langkah manusia, sehingga air hujan lebih sulit untuk masuk ke dalam tanah dan lebih banyak air hujan yang menjadi aliran permukaan. Terjadi juga pencabutan batang dan akar yang mengakibatkan agregat tanah menjadi tidak stabil sehingga mudah terdispersi oleh butir air hujan dan terbawa oleh gaya dari aliran permukaan.

Pada erosi yang terjadi di plot bawah, setelah pemanenan dilakukan terjadi kejadian hujan dengan tebal hujan yang tinggi. Pada hujan pertama dengan tebal hujan 40,06 mm setelah pemanenan terjadi, menimbulkan erosi sebesar 10,85 kg/ha. Selanjutnya dilakukan pemanenan kembali dan esoknya terjadi hujan dengan tebal hujan 32,48 mm, menimbulkan erosi sebesar $12,10 \mathrm{~kg} / \mathrm{ha}$. Erosi lebih besar meskipun tebal hujan lebih rendah kemungkinan dikarenakan pemanenan yang sudah lebih meluas dan terus menerus sehingga lebih banyak bagian plot yang tidak tertutupi rumput. Setelah itu, besar erosi terus menurun pada Tabel 7, dikarenakan tanah sudah lebih stabil dan dibantu juga oleh limbah bekas panen berupa batang rumput kolonjono yang biasanya dibiarkan oleh petani begitu saja di atas lahan sampai kemudian datang kembali untuk menanam rumput. Hal ini juga terjadi pada plot tengah saat kejadian hujan dengan tebal hujan 23,74 $\mathrm{mm}$ dan plot atas saat kejadian hujan dengan tebal hujan 14,37 $\mathrm{mm}$, yang sebelumnya terdapat kegiatan pemanenan pada plot tersebut. Sementara itu, pada kejadian hujan dengan tebal hujan 14,37 $\mathrm{mm}$ yang menimbulkan nilai erosi ekstrim pada plot atas meskipun sebelumnya tidak ada kegiatan pemanenan, disebabkan oleh kejadian hujan yang terjadi selama 3 hari berturut-turut sehingga tanah cenderung menjadi lebih lembab dan air hujan yang jatuh menjadi aliran permukaan yang berpotensi untuk meningkatkan erosi. Menurut Fiener, et al., (2018), lahan yang diolah tingkat erosinya lebih tinggi dan tekanan manusia terhadap lahan akan meningkatkan erosi (Evans, et al., 2017). Erosi pada lahan pertanian lebih tinggi daripada lahan hutan (Anache, et al., 2017; Nearing, et al., 2017).

Pengaruh tebal hujan terhadap aliran permukaan, tebal hujan terhadap erosi, dan aliran permukaan terhadap erosi pada tiap plot di lokasi penelitian diprediksi menggunakan regresi linear sederhana menggunakan SPSS 22. Korelasi yang erat dan pengaruh yang signifikan terjadi antara tebal hujan terhadap aliran permukaan, tebal hujan terhadap erosi, dan aliran permukaan terhadap erosi. Hubungan tebal hujan terhadap aliran permukaan pada tiap plot ditampilkan pada Tabel 9, hubungan tebal hujan terhadap erosi ditampilkan pada Tabel 10, dan hubungan aliran permukaan terhadap erosi ditampilkan pada Tabel 11 . Erosi tanah tahunan dan aliran permukaan tahunan diperoleh menggunakan persamaan yang diperoleh dari hasil analisis regresi linier dengan input data tebal hujan Hutan Wanagama I pada tahun 2017 yang diperoleh dari stasiun pengamatan milik Balai Besar Wilayah Sungai Serayu Opak (BBWSSO). Persamaan untuk menghitung erosi berdasarkan data aliran permukaan dapat dilihat pada Persamaan 5, 6, dan 7 untuk plot atas, tengah dan bawah. Adapun persamaan untuk menghitung erosi berdasarkan data hujan disajikan pada Persamaan 8, 9, dan 10.

$$
\begin{aligned}
& \gamma=0,121+2,731 \chi \ldots \ldots \ldots \ldots \ldots . . . \\
& \gamma=\text { erosi plot atas } \\
& \chi=\text { aliran permukaan plot atas } \\
& \gamma=0,136+2,682 \chi \ldots \ldots \ldots \ldots . . . . \\
& \gamma=\text { erosi plot tengah } \\
& \chi=\text { aliran permukaan plot tengah } \\
& \gamma=-0,278+3,191 \chi \ldots \ldots \ldots \ldots . . \\
& \gamma=\text { erosi plot bawah } \\
& \chi=\text { aliran permukaan plot bawah } \\
& \gamma=-2,108+0,261 \chi \ldots \ldots \ldots \ldots . . . \\
& \gamma=\text { erosi plot atas } \\
& \chi=\text { tebal hujan }
\end{aligned}
$$




$$
\begin{aligned}
& \gamma=-2,059+0,248 \chi \\
& \gamma=\text { erosi plot tengah } \\
& \chi=\text { tebal hujan } \\
& \gamma=-3,773+0,372 \chi \\
& \gamma=\text { erosi plot bawah } \\
& \chi=\text { tebal hujan }
\end{aligned}
$$

Sebelum dilakukan prediksi besar aliran permukaan tahunan, koefisien aliran permukaan tahunan, dan besar erosi tahunan, terlebih dahulu dilakukan uji beda menggunakan Kruskal-Wallis H Test. Uji ini digunakan untuk menguji perhitungan dari hasil persamaan regresi apakah memiliki perbedaan yang signifikan dengan hasil perhitungan yang didapat dari penelitian yang telah dilakukan. Apabila tidak ada perbedaan yang signifikan antara hasil perhitungan dan hasil persamaan regresi, maka persamaan regresi dapat digunakan untuk memprediksi. Kruskal-
Wallis $\mathrm{H}$ Test digunakan karena termasuk uji non-parametris. Karena termasuk uji non-parametris, uji ini dapat digunakan untuk menguji kelompok data yang distribusinya tidak normal. Bila data yang dimiliki terdistribusi normal, hasil akan lebih baik bila menggunakan uji ANOVA.

Hasil uji menghasilkan nilai signifikansi tiap uji yang dilakukan lebih besar dari 0,05. Dengan demikian tidak ada perbedaan yang signifikan antara nilai aliran permukaan dan erosi hasil perhitungan langsung dengan metode plot kecil dengan nilai aliran permukaan dan erosi hasil perhitungan persamaan regresi linear. Dengan ini maka persamaan linear yang diuji dapat digunakan untuk memprediksi besar aliran permukaan ataupun erosi. Pada penelitian ini, persamaan regresi tersebut digunakan untuk memprediksi besar erosi tahunan. Hasil perhitungan erosi pada lahan kolonjono (Brachiaria mutica) pada tahun 2017 dapat dilihat pada Tabel 12.

Tabel 12. Erosi potensial pada lahan rumput kolonjono di Hutan Wanagama I tahun 2017

\begin{tabular}{lrrrr}
\hline \multirow{2}{*}{ Bulan } & \multirow{2}{*}{ Tebal hujan $(\mathbf{m m})$} & \multicolumn{3}{c}{ Erosi (Kg/Ha) } \\
\cline { 3 - 5 } & & \multicolumn{1}{c}{ PA } & \multicolumn{1}{c}{ PB } \\
\hline Januari & 312 & 83,71 & 77,32 & 113,66 \\
Februari & 291,5 & 78,05 & 72,09 & 105,94 \\
Maret & 479,5 & 129,91 & 119,99 & 176,73 \\
April & 168,5 & 44,12 & 40,75 & 59,62 \\
Mei & 86,5 & 21,51 & 19,86 & 28,75 \\
Juni & 79,5 & 19,58 & 18,08 & 26,11 \\
Juli & 0,8 & 0,00 & 0,00 & 0,00 \\
Agustus & 0,9 & 0,00 & 0,00 & 0,00 \\
September & 97,9 & 24,65 & 22,77 & 33,04 \\
Oktober & 93,1 & 23,33 & 21,54 & 31,23 \\
November & 611,1 & 166,21 & 153,52 & 226,28 \\
Desember & 264 & 70,47 & 65,09 & 95,58 \\
\hline Erosi Kg/Ha/Tahun & 2485,3 & 661,52 & 611,01 & 896,94 \\
Erosi Ton/Ha/Tahun & 2,485 & 0,662 & 0,611 & 0,897 \\
\hline
\end{tabular}

Keterangan: $\mathrm{PA}=$ Plot atas, $\mathrm{PT}=$ Plot tengah, $\mathrm{PB}=$ Plot bawah

Plot atas atau lereng bagian atas menghasilkan erosi sebesar 0,662 ton/ha/tahun, plot tengah atau lereng bagian tengah menghasilkan erosi sebesar 0,611 ton/ha/tahun, dan plot bawah atau lereng bagian bawah menghasilkan erosi sebesar 0,897 ton/ha/tahun. Hasil ini dapat diklasifikasikan berdasarkan Tabel 3 . Berdasarkan klasifikasi yang dilakukan, kelas erosi seluruh plot termasuk ke dalam kelas erosi I, tetapi memiliki kedalaman tanah yang berbeda. Pada plot tengah dan bawah memiliki kedalaman tanah yang dangkal $(30-60 \mathrm{~cm})$ sehingga keduanya memiliki tingkat bahaya erosi Sedang (II S). Sementara plot atas memiliki kedalaman tanah sangat dangkal $(<30 \mathrm{~cm})$ sehingga 
memiliki tingkat bahaya erosi Berat (III B).

\section{KESIMPULAN DAN SARAN}

\section{Kesimpulan}

Rumput berperan baik dalam meredam aliran permukaan dan erosi. Ketiga plot mempunyai koefisien aliran yang baik, yaitu $4,82 \%$ tebal hujan menjadi aliran permukaan pada plot atas, $4,47 \%$ tebal hujan menjadi aliran permukaan pada plot tengah, dan 5,29\% tebal hujan menjadi aliran permukaan pada plot bawah. Tingkat erosi pada lahan rumput semuanya tergolong sangat rendah. Dihasilkan erosi sebesar $52,52 \mathrm{~kg} / \mathrm{ha}$ pada plot atas, 48,44 $\mathrm{kg} / \mathrm{ha}$ pada plot tengah, dan $57,90 \mathrm{~kg} / \mathrm{ha}$ pada plot bawah. Diperkirakan erosi tahunan yang terjadi sebesar 0,662 ton/ha/tahun pada plot atas, 0,611 ton/ha/tahun pada plot tengah, dan 0,897 ton/ha/tahun pada plot bawah. Hasil analisis statistik menunjukkan tebal hujan berpengaruh secara signifikan terhadap besarnya aliran permukaan dan erosi pada ketiga plot. Hasil analisis juga menunjukkan aliran permukaan berpengaruh secara signifikan terhadap besarnya erosi pada ketiga plot rumput.

\section{Saran}

Penelitian lebih lanjut mengenai erosi pada lahan rumput kolonjono dengan sistem tumpangsari maupun bentuk penanaman lainnya menarik untuk dilakukan karena beragamnya sistem penanaman rumput kolonjono di Hutan Wanagama I. Disarankan pula penelitian seperti ini untuk dilakukan dalam waktu yang lebih lama sehingga diperoleh data erosi yang lebih lengkap.

\section{UCAPAN TERIMA KASIH}

Penulis sangat bersyukur atas selesainya penelitian ini dengan dukungan dana dari PDUPT. Terima kasih juga penulis sampaikan kepada pengelola Wanagama yang telah memfasilitasi penelitian ini di lapangan.

\section{DAFTAR REFERENSI}

Anache, J.A.A., Edson, C.W., Paulo T.S.O., Dennis, C.F. \& Nearing, M.A. (2017). Runoff and Soil Erosion Plot-scale Studies Under Natural Rainfall: A Meta-analysis of the Brazilian Experience. Catena, 152, 29-39.

Anonim. (2009). Peraturan Direktur Jenderal Rehabilitasi Lahan dan Perhutanan Sosial No. P.04/VSET/2009 Tentang Pedoman Monitoring dan Evaluasi Aliran Sungai. Jakarta: Kementerian Kehutanan Republik Indonesia.

Arsyad, S. (2010). Konservasi Tanah dan Air. Bogor: InstPertanian Bogor.

Blandon, P. (1985). Agroforestry and Portfolio Theory. Agroforest Syst, (3), 239-249.

https://doi.org/10.1007/BF00046957.

Doke, M.A., Kusumandari, A. \& Senawi. (2018). Tingkat Erosi dan Rancangan Konservasi Tanah dan Air di Sub DAS Waewoki, DAS Asesa. Jurnal Manusia dan Lingkungan, 25(1), 717.

Ernawati, J. (2016). Jejak Hutan Wanagama. Jakarta: Deutsche Gesellschaft Fur Internationale Zusammenabeit (GIZ) GmBH Forest and Climate Change Programme (Forclime).

Evans, B.A., Collins, R., Zhang, A.L., Foster, Y., Boardman, I.D.L., Sint, J., Lee, H. \& Griffith, M.R.F. (2017). A comparison of conventional and 137Cs-based estimates of soil erosion rates on arable and grassland across lowland England and Wales., EarthScience Rev. J, 173, 49-64. 
Fiener, P., Wilken, F., Aldana-Jague, E., Deumlich, D., G'omez, J.A., Guzm'an, G., Hardy, R.A., Quinton, J.N., Sommer, M., Van Oost, K. \& Wexler, R. (2018), Uncertainties in assessing tillage erosion - How appropriate are our measuring techniques?, Geomorphology doi:10.1016/j.geomorph.2017.12.03

Hardjowigeno, S. (2011). Evaluasi Kesesuaian Lahan dan Perencanaan Tataguna Lahan. Yogyakarta: Gadjah Mada University Press.

Kertis, T.A. \& Livari, C.A. (2006). Soil Erosion on Cropland in the United States: Status and Trends for 19822003. Proceedings Eighth Fed. Interag. Sediment. Conf. (8thFISC), Reno, NV, USA.

Kusumandari, A. (2013). Buku Ajar Konservasi Tanah dan Air. Laboratorium Pengelolaan Daerah Aliran Sungai. Yogyakarta: Departemen Konservasi Sumberdaya Hutan. Fakultas Kehutanan. Universitas Gadjah Mada.

Liu, Y., Xin, Y., Xie, Y., \& Wang., W. (2019). Effects of Slope and Rainfall Intensity on Runoff and Soil Erosion from Furrow Diking under Simulated Rainfall. Catena, 177(June), 92-100. https://doi.org/10.1016/j.catena.2019. $\underline{02.004}$

McConkey, B.G., Lobb, D.A., Li, J. M. W. B. S. \& Krug, P.M. (2010). Soil Erosion on Cropland: Introduction and Trends for Canada. Canadian Biodiversity: Ecosystem Status and Trends. Technical Thematic Report No. 16 Published by the Canadian Councils of Resource Ministers.

Nearing, M.A., Xie, Y., Liu, B., \& Ye, Y. (2017). Natural and anthropogenic rates of soil erosion. Int. Soil Water Conserv. Res. 5, 77-84. http://dx.doi.org/10.1016/j.iswcr.2017 .04 .001

Nurjanto, H.H., Supriyo, H., Widyastuti, S.M., Kabirun, S., Johan, E., \& Matsue, N. (2016). Smectite Under Heavy Clay Soils Development at FRE Wanagama Forest Area. Malaysian Journal of Soil Science, 20(May), 1-18.

Ratnaningrum, Y.W.N., \& Indrioko, S. (2014). Variation on Genotypes and Flowering Characters Affecting Pollination Mechanisms of Sandalwood (Santalum album Linn, Santalaceae) Planted on ex-situ Gene Conservation in Yogyakarta, Indonesia. Eurasean J For Res, VI, 167-179.

Ribolzil, O. C., Evrard, O., Huon, S., de Rouw, A., Silvera, N., Latsachack, KO., Soulileuth, B., Lefèvre, I., Pierret, A., Lacombe, G., Sengtaheuanghoung, O., \& Valentin. (2017). From shifting cultivation to teak plantation: effect on overland flow and sediment yield in a montane tropical catchment. Sci. Rep., 7, 3987.

Stewart, J.L. \& Simons, A.J. (1994). Gliricidia sepium: a multipurpose forage tree legume., Gutteridge. UK: Forage Tree Legumes in Tropical Agriculture. CAB International, Oxon.

Subagiya., Sriyono, E., \& Achmad, N. (2016). Pengaruh Erosi dan Sedimentasi Terhadap Pelestarian Layanan Umur Manfaat Waduk. Jurnal Teknik, 6(1), 22-31.

Supriyo, H., Faridah, E., Atmanto, W.D., Figyantika, A., \& Fajri, A. K. (2009). Kandungan C-Organik dan N Total 
pada Seresah dan Tanah pada 3 Tipe Fisiognomi (Studi Kasus di Wanagama I, Gunung Kidul, DIY). Jurnal Ilmu Tanah Dan Lingkungan., 9(1), 49-57.

Suseno, O. H. (2004). Sejarah Wanagama I. Dalam: Pramudyo, RIS., OH Suseno, H. Supriyo, Soekotjo, M. Naiem, U Iskandar. Dari Bukit-Bukit Gundul sampai ke Wanagama-I. Yogyakarta: Yayasan Sarana Wana Jaya.

Van Loo, M., Dusar, B., Verstraeten, G., Renssen, H., Notebaert, B., D'Haen, K., \& Bakker, J. (2017). Human induced soil erosion and the implications on crop yield in a small mountainous Mediterranean catchment (SW-Turkey). Catena, 149, 491-504.

https://doi.org/10.1016/j.catena.2016. $\underline{08.023}$

Wang, Y., You, W., Fan, J., Jin, M., Wei, X., \& Wang, Q. (2018). Effects of subsequent rainfall events with different intensities on runoff and erosion in a coarse soil. Catena, 170(June), 100-107. https://doi.org/10.1016/j.catena.2018. $\underline{06.008}$
Wischmeier, W.H. \& Smith, D.D. (1978). Predicting Rainfall Erosion Losses: A Guide to Conservation Planning. Washington DC: Government Printing Office.

Wu, X., Wei, Y., Wang, J., Xia, J., Cai, C., \& Wei, Z. (2018). Effects of Soil Type and Rainfall Intensity on Sheet Erosion Processes and Sediment Characteristics Along the Climatic Gradient in Central-south China. Science of the Total Environment, 621, 54-66. https://doi.org/10.1016/j.scitotenv.20 $\underline{17.11 .202}$

Yu, L., Zhang, K.Y., \& Liu. (2017). Measuring and modelling soil erosion and sediment yields in a large cultivated catchment under no-till of Southern Brazil. Soil Tillage Res., 174, 24-33.

Yuferev V.G., Zavalin A.A., Pleskachev Y.N., Vdovenko A.V., Fomin S.D., \& Vorontsova E.S. (2019). Degradation of landscapes in the South of the Privolzhsky Upland. J. For. Sci., 65, 195-202.

https://www.agriculturejournals.cz/w eb/jfs.htm?type $=$ article \&id $=141 \_201$ 8-JFS 